\title{
Prospecting for uranium in central East Greenland
}

\section{Bjarne Leth Nielsen and Agnete Steenfelt}

The uranium prospecting programme commenced in East Greenland between $72^{\circ}$ and $76^{\circ} \mathrm{N}$ in 1973 was continued during 1974 and included airborne radiometric surveying, field investigations in anomalous areas and a geochemical sampling programme. Some of the results of the field work and the geochemical work are described here. The prospecting activity was accomplished in collaboration with the Danish Atomic Energy Commission's Research Establishment, Ris $\varnothing$, and Rheinisch-Westfälische Technische Hochschule, Aachen.

The field parties and the airborne prospecting work were served by a helicopter and aircraft chartered from Heliswiss, Bern and Greenlandair Charter A/S. Stordal, west of Hold with Hope, was the base camp for all operations. During August, some of the field teams were served by the GGU cutter Jytte.

\section{Radiometric prospecting and uranium mineralisation}

The airborne radiometric survey included: (1) gamma-spectrometric reconnaissance flights which represented a continuation of last year's activity (Nielsen \& Larsen, 1974); and (2) a helicopter-borne, high sensitivity scintillometric survey in selected areas of above average radioactivity. These areas were first located in 1973 by aeroradiometric spectrometry and, in the course of this year's investigations, important radioactive anomalies were recorded in Middle Devonian rhyolites in the southern part of Gieseckes Bjerge.

Detailed work in the field showed that uranium mineralisation has taken place in fault and crush zones in acid volcanic rocks belonging to a series of Devonian continental sediments and volcanics (Bütler, 1954; Graeter, 1957). The mineralisation occurs in a lower series of quartz porphyries and tuff breccias separated from an upper series of rhyolites by fluviatile sandstones. The radioactive hot spots are currently restricted to the lower series of quartz porphyries which in the area have a maximum elevation of $200-300 \mathrm{~m}$ above sea level and a surface distribution of approximately $1 \mathrm{~km}^{2}$.

The host rhyolites are enriched in radioactive elements by a factor of 2-3 compared to rhyolites elsewhere. The mineralised zones are 1-20 metres wide and strike $120^{\circ}$. Radioactivity changes strongly within the zones, ranging from background count rates of 250 counts per second (cps) to more than $10000 \mathrm{cps}$. Random uranium analyses on rock samples show uranium contents of up to $2000 \mathrm{ppm}$, with the average content being 500-700 ppm. The thorium content is generally less than $50 \mathrm{ppm}$.

The radioactive mineral occurs as $1 \mathrm{~mm}$ black grains disseminated in the rhyolite, and as thin veins and coatings along cracks. Preliminary studies indicate that the mineral belongs to the group of thucolites. Secondary uranium minerals of green fluorescence are frequently seen as greyish coatings on the rock.

As a working hypothesis, the genesis of the ore is regarded as redistribution of uranium influenced by the activity of hydrocarbons within the rhyolites, partly controlled by the fault pattern of the area. 
Detailed field work in Gieseckes Bjerge and in rhyolites and radioactive anomalous sandstone areas on Gauss Halv $\emptyset$ and Hudson Land is planned for the 1975 field season.

\section{Geochemical prospecting}

Due to the severe topography and numerous local ice caps, radiometric flights give an uneven coverage. To investigate the applicability of geochemical methods and sampling to such terrain a geochemical sampling programme was carried out including: (1) a helicopter-supported stream water and stream sediment survey on a regional scale; (2) detailed sampling by field teams in areas of anomalous radioactivity; and (3) sampling to control seasonal variations in sampling media.

The regional survey was centred upon the Devonian-Carboniferous sedimentary basin on Hudson Land, Gauss Halvø, Strindberg Land, Gunnar Andersson Land, Ymer $\emptyset$ and Geographical Society $\varnothing$, and the Caledonian crystalline complex on Kuhn $\emptyset .280$ localities were sampled, with a sampling density of 1 sample per $25-30 \mathrm{~km}^{2}$ in the sedimentary basin and 1 sample per $10 \mathrm{~km}^{2}$ in the crystalline complex. The sample sites were chosen in accordance with the drainage pattern. At each locality the sample comprised: 1 litre of stream water in a polyethylene bag; three polyethylene tubes each containing $7 \mathrm{ml}$ of stream water; $200-300 \mathrm{~g}$ of stream sediment, preferably fine fractions.

The detailed sampling comprised stream water, seepage water, stream sediments and soil. The numbers of samples within the different areas is given in Table 4. Furthermore, the water of 15 selected streams was analysed by ion-exchange resins for heavy metals and uranium. This method is described by Asmund (1974).

Seasonal variation in the concentration of elements in the water and sediment of a river were estimated by taking duplicate samples of water and sediment from the same site in Storelv, Hudson Land, every sixth day during July and August. The preliminary results of the water analyses show an increase in the content of uranium as well as in the content of dissolved matter towards the end of the season.

Table 4. Distribution of geochemical samples

\begin{tabular}{|c|c|c|c|c|}
\hline \multirow[t]{3}{*}{ Sample areas } & \multicolumn{3}{|c|}{ Number of samples } & \multirow[b]{3}{*}{ soil } \\
\hline & \multicolumn{2}{|c|}{ water } & \multirow{2}{*}{$\begin{array}{c}\text { stream } \\
\text { sediment }\end{array}$} & \\
\hline & 11 & $3 \times 7=1$ & & \\
\hline Central Kuhn $\emptyset$ & 31 & 31 & 29 & \\
\hline Ritom Sø, Hudson Land & 20 & 20 & 20 & \\
\hline Southern Gieseckes Bjerge & & 70 & 77 & 25 \\
\hline Kap Franklin area & & 92 & 83 & 35 \\
\hline Arkosedal & & 12 & 19 & 21 \\
\hline Stauning Alper & & 5 & 22 & 7 \\
\hline
\end{tabular}


Table 5. Programme for sample analyses

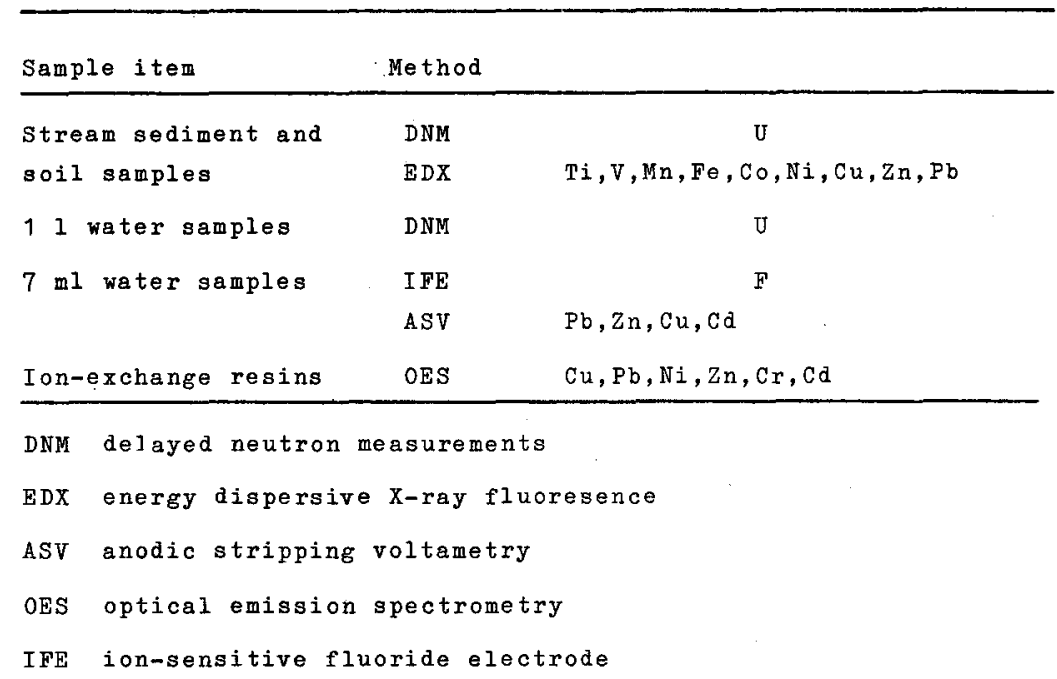

\section{Sample preparation}

Stream sediments and soil samples are dried and sieved, the 150 fraction being used for analysis. The 1 litre water samples are preconcentrated by precipitation with ferrihydroxide. The programme for sample analyses is given in Table 5 .

\section{Preliminary results}

The analyses so far carried out indicate that the typical uranium content of stream sediments from the Devonian basin is $2-3 \mathrm{ppm}$, whereas in the crystalline complex of Kuhn $\varnothing$ stream sediments contain 10-11 ppm on average. High contents have been found in radiometric anomalous areas and in a few additional places.

The conductivity of all 1 litre water samples has been measured, the samples from the crystalline complex being significantly lower (10-50 $\mu$ mho) than samples from the sedimentary deposits (mainly within 60-160 $\mu$ mho).

Direct DNM-measurement of the $7 \mathrm{ml}$ water samples was attempted, but gave poor results and has been discontinued.

Preliminary results from the DNM analysis of precipitates indicates that the uranium content of stream water from the Devonian sediments is of the magnitude $0.2-0.8 \mathrm{ppb}$ and $<0.1-0.2 \mathrm{ppb}$ from the crystalline complex of Kuhn $\emptyset$. The detection limit for the method is estimated at $0.1 \mathrm{ppb}$. The highest observed value was approximately $10 \mathrm{ppb}$.

The DNM analyses of the ion-exchange resins gave values for the uranium content of the stream water which are in good agreement with the results from the precipitation method. 


\section{References}

Asmund, G. 1974: Hydrogeochemical investigations on river water in West, South and East Greenland. Rapp. Gronlands geol. Unders. 65, 71-73.

Bütler, H. 1954: Die stratigraphische Gliederung der Mitteldevonischen Serien im Gebiete von Kap Franklin am Kejser Franz Josephs Fjord in Zentral-Ostgrönland. Meddr Grønland $116,7,126 \mathrm{pp}$.

Graeter, P. 1957: Die sauren Devonischen Eruptivgesteine des Kap Franklingebiets am Kejser Franz Josephs Fjord in Zentral-Ostgrönland. Meddr Grønland 155,3, 102 pp.

Nielsen, B. L. \& Larsen, H. C. 1974: Airborne geophysical survey in central East Greenland. Rapp. Grфnlands geol. Unders. 75, 73-76.

\section{Sedimentology and stratigraphy of the Middle Jurassic - Lower Cretaceous rocks of the Wollaston Forland - Kuhn $\varnothing$ area, central East Greenland}

\section{Finn Surlyk and Lars B. Clemmensen}

The present investigation was carried out in order to gain information concerning the stratigraphy and sedimentology of the Upper Jurassic and Lower Cretaceous sediments in central East Greenland (fig. 27). We were especially interested in the following topics:

(1) To delineate sedimentary facies and interpret their depositional environment.

(2) To erect a strict lithostratigraphical scheme for the sedimentary sequence.

(3) To date the tectonic activity controlling the sedimentation at the Jurassic-Cretaceous boundary.

\section{Structural and depositional framework}

The Bathonian - Middle Volgian sediments of the Wollaston Forland area were deposited on the peneplaned surface of large, slightly westward tilted, fault-blocks in supratidal and marine nearshore intertidal to outer shelf environments. The sediments consist of light sandstones grading upwards into interlaminated sand-mudstone and dark mudstones deposited under euxinic conditions.

This first depositional cycle included in the Jameson Land Group (Surlyk et al., 1973) came to an end in early Middle Volgian (late Jurassic) time when large-scale faulting, partly along old N-S trending fault systems, broke up the East Greenland shelf into several westward tilted fault blocks (Vischer, 1943). Along the fault-scarps forming 